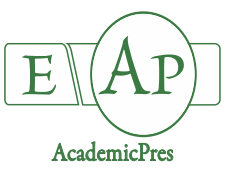

Hălălișan A-F et al. (2020)

Notulae Botanicae Horti Agrobotanici Cluj-Napoca 48(3):1683-1698

DOI: $10.15835 /$ nbha48312007

Research Article

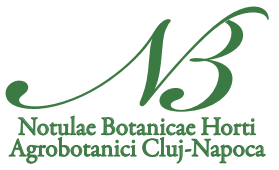

\title{
The relationships between forestry sector standardization, market evolution and sustainability approaches in the communist and post- communist economies: the case of Romania
}

\author{
Aureliu-Florin HĂLĂLIȘAN ${ }^{1}$, Adelin-Ionuț NICORESCU ${ }^{1}$, \\ Bogdan POPA ${ }^{1}$, Nikolay NEYKOV ${ }^{2}$, Viorel MARINESCU ${ }^{1}$, \\ Ioan Vasile ABRUDAN ${ }^{1 *}$
}

\author{
${ }^{1}$ Transilvania University of Brasov, Faculty of Silviculture and Forest Engineering, 1 Sirul Beethoven, Brasov, Romania; \\ aureliu.halalisan@unitbv.ro; adelin.nicorescu@student.unitbv.ro;popa.bogdan@unitbv.ro; marinescuviorel@ymail.com; \\ abrudan@unitbv.ro (*corresponding author) \\ ${ }^{2}$ University of Forestry, Faculty of Business Management, 10 Kliment Ohridsky Blvd., Sofia, Bulgaria; nneykov@Itu.bg
}

\begin{abstract}
This paper analyses how forestry standardization process interrelates with the national and sectoral economic characteristics and the evolution of sustainable forest management implementation in communist and post-communist Romania. The study used the database of Romanian Standardization Association for selecting forestry specific standards, which have been issued since 1949. The selected standards were grouped according to their scope, issuing period and international recognition, and the obtained distributions were analysed in the context of sectoral economic evolution. In the communist period, the long-term sectoral strategy, which was centred on sustainable forest management, added value products and export was accompanied by a sustained effort in standardizing the design and quality of forest products, as well as the needed processes. Based on standardization, the efficient and integrated forest industry acted in the framework of a prescriptively regulated sustainable forest management. Mandatory national standards from the communist period have been mostly replaced by post-communist consensual international standards. The opportunities of a market economy and EU trade supported a private forest industry that is increasingly efficient, productive and innovative. However, considering the high forestry sector environmental and social sustainability requirements, the state authorities must carefully address their mission of balancing different interests, for which standardization may provide very useful tools.
\end{abstract}

Keywords: economic evolution; Romanian forestry; standardization; sustainability

\section{Introduction}

World Commission on Environment and Development (1987) defined sustainability as development which meets the needs of the present without compromising the ability of future generations to meet their own needs. Other definitions argue that sustainability requires a balance between ecological, economic and social dimension of development (Chang et al., 2017). Sustainability consideration in managing companies emerged 
in the 1930s, far before the release of the Brundtland report (Carroll, 1999) with some articles on corporate responsibilities. After the release of the Brundtland Report in 1987, the concept of sustainable development has been continuously playing a determinant role in economy (Hopwood, 2005).

The current global context is marked by a growing interest in the integrated promotion of the sustainability concept, as highlighted by the adoption, in 2015, of the 17 Sustainable Development Goals (SDGs). The sustainable approach in the forestry sector becomes more important as its contribution to the SDGs is increasingly significant (Timko et al., 2018): a sustainable forestry sector contributes directly to SDG 15 - Life on Land: Protect, Restore, and Promote Sustainable Use of Terrestrial Ecosystems; Sustainably Manage Forests; Combat Desertification; Halt and Reverse Land Degradation, and Halt Biodiversity Loss (Baumgartner, 2019), but, due to the possible positive externalities of forest ecosystems, it is also closely connected with other goals such as SDG 2 Zero Hunger, SDG 6 Clean Water and Sanitation, SDG 8 Decent Work and Economic Growth, SDG 10 Reduced Inequalities or SDG 13 Climate Action (Le Blanc, 2015). As long as forestry is at the core of green economy, it can be an important source of sustainable green origin products, thus having a solid contribution to Responsible Consumption (SDG 12) and Sustainable Communities (SDG 11), goals linked to consumption but also to the source of materials and products for that consumption (Timko et al., 2018). Notably, SDG 12 is relevant for the supply chain sustainability (Silva and Figueiredo, 2020) requiring policies to create a conductive environment for changing social and physical infrastructure, markets, and a deep transformation of business practices along the global value chain (UN, 2018).

To achieve sustainable development, industries should be able to perform sustainable and environmentally friendly production processes (Nur et al., 2018), positively impacting the three fundamental dimensions - economic, environmental and social (Grefrath et al., 2017). Forestry has an important potential in positively influencing all three dimensions, and the multiple benefits that forestry provides to society include not only the sustainable forest management (FM) itself (Aplet et al., 1993; Sample and Sedjo, 1996; Siry et al., 2005; Linser et al., 2018) but also the use of the forest resource in related economic sectors (Voces et al., 2012; Gaurav et al., 2017; Ramage et al., 2017). From this perspective, the concept of forestry sector sustainability includes general aspects of environmental impacts referring to the ratio between renewable and non-renewable resources, impacts on biodiversity or products life cycle (Baumgartner and Ebner, 2010). It can also address microeconomic matters such as the competitive environment in the forest industry (Baumgartner and Rauter, 2017), or macroeconomic subjects such as the added value in wood processing and its effects on society (Lahtinen and Toppinen, 2008), the technological efficiency of processes or innovation (Baumgartner and Rauter, 2017; Hurmekoski et al., 2018). The concern for a sustainable approach in the forestry sector has led to the identification of good practices that have often been translated into guidelines, regulations, indicators or standards. These tools have been widely adopted and continuously adapted to the contextual or conceptual evolution, depending on the country, sector and organisation requirements, including those having an economic perspective. In this context, standardization in forestry sector can be regarded as a tool for promoting sustainability.

In general terms, standardization is defined as the activity of establishing, with regard to current or potential problems, provisions for common and repeated use, aimed at the achievement of the optimum degree of order in a given context (ISOI-IEC, 1991). The sustainable development could be defined as comparable growth in all the regions all over the world and sectors of national economies (Wiśniewska, 2015). Thus, the sustainable development concept has important benefits on supply chains through suitability of products, processes and services for their intended purposes and facilitation of technological cooperation. The standardisation is closely linked to products' diversification, innovation and customer needs. The standards intend to promote compatibility, interoperability and quality (Xie et al., 2016). There is a positive correlation between innovation and standards in many cases (Lecocq and Demil, 2006; Hashem and Tann, 2007; Rysman and Simcoe, 2008) with an impact on both products and management. However, in some cases, the creativity and innovation are constrained by standardisation and companies focus mainly on successful 
commercialization (Hill and Rothaermel, 2003; Hamel, 2006). From a competitive business view, the companies must diversify their offers to meet customer's demands (Baud-Lavigne et al., 2012). In this case, the standardization is challenged and a shift from mass production to mass customization is difficult. Changes from the traditional organization, with production segmented into very narrow compartments (Fornasiero et al., 2015) to mass customization with organizations structured to create more individuality products have impacts on optimisation of costs, efficiency, wastes elimination and cost and flexibility/market sensitive strategy to respond to real time changes in demand (Stratton and Warburton, 2003; Bruce et al., 2004).

In the forestry sector, standardization means implementing norms, principles and criteria, or at least combining them, with the purpose of modelling and improving forest management (hereafter FM) and forest industry specific processes as well as customising the products. Forestry standardisation has a significant potential for promoting sustainability both by efficiently using the forest resources and by creating an economically enabling environment for products and services (Van Bueren and Blom, 1997). Forestry sector standards refer to silvicultural treatments, logging, wood processing, production of complex products that include wood or non-wood components etc. They provide the needed guidance for design, processing, product delivery, test methods, product quality and performance, and human safety. Efficient use of raw materials, safe work and facilitated trade are only some of the sustainability outcomes of forestry standardisation. They are also important tools for implementing the concept of economic sustainability, depending on the policies and economic development of a country or region. In the forestry sector, there are limited research initiatives oriented towards the interconnections between standardization and sustainability concept evolution, especially if aspects related to the economic evolution are considered (Van Bueren and Blom, 1997).

The present paper aims to analysing the standardization process in connection with the evolution of sustainable forest management (FM) implementation and sectoral economic evolution development during communism and post-communism transition in Romania.

\section{Materials and Methods}

\section{Framework}

Snapshot on country general economic development and forestry sector evolution

Economists are defining several steps in Romanian economic evolution for the analysed period (Iancu and Pavelescu, 2018): i) 1945 to 1956 - post war recovery and consolidation of centralized economy; ii) 1956 to 1970 - soviet model industrial development and Council for Mutual Economic Assistance (CMEA) oriented external trade; iii) 1970 to 1980 - technological development, heavy infrastructure investments and increased western trade orientation; iv) 1980 to 1990 - public debts and technological crisis and v) after 1990 - market economy transition, privatization and European Union (EU) accession. Forestry sector has followed these major economic orientations (Figure 1).

Between 1945 and 1956 (Figure 1), despite a very difficult economic situation after the World War II, Romania managed to reach the economic level of 1938 (considered as the peak for the period before the World War II) in 1950 (Iancu and Pavelescu, 2018). Based on imposed economic convention, many of the Romanian resources were exploited for paying war debts to Soviet Union. Land and industry were nationalized and there was a rapid process of adopting a centralized economy, based on five-year-plans starting from 1950. The development of centralized planned heavy industry started using the soviet model. This was the worst period for the forestry sector: it started with the nationalization of private forest lands, and continued with applying the Soviet directives: clear cuts on large areas and planting of fast-growing species (Munteanu et al., 2016). The Sovromlemn Society was established based on the Convention for the Exploitation, Industrialization and Valuation of Wood Materials signed in 1946 (Banu, 2004), with the purpose of wood harvesting, processing and distribution in the Soviet Union interest (Banu, 2004). Consequently, in some areas of the country, the 
annual allowable cut has been exceeded by 4-7 times, without following any rules (Marcean, 2002; Macovei, 2011) leading to the disappearance of large areas of old-growth forests (Veen et al., 2010; Knorn et al., 2012).

Communist period



Post- Communist period

Compulsory character of standards

Consensual character of standards

Figure 1. Timelines of Romanian market-orientation and standardisation

Sources: Iancu and Pavelescu (2018), Banu (2004), Zaman and Pavelescu (2018), INS (1992), APMR (2018)

The second period, from 1956 to 1970 (Figure 1), is characterized by the efforts for developing heavy industry and the orientation towards a self-sufficient economy, including a significant diversification of products. Romanian international trade was mainly oriented towards CMEA member states $(2 / 3$ of the external trade), although the international relationships with non-communist Western economies slowly increased (Zaman and Georgescu, 2018). The Gross Domestic Product (GDP) doubled during this period (Iancu and Pavelescu, 2018). Forest industry increasingly focused the production of added value products for the communist countries markets, while round-wood export decreased. Notably, starting from this period most of the forest industry products were exported, the internal consumption holding a decreasing proportion (INS, 1992).

The third period (Figure 1), between 1970 and 1980 was a rather prolific economic period, although the investments, for which Romania heavily borrowed from the west, started to have bad returns (Ban-Ner and Montias, 1991). Romania recorded the highest rates of economic development and the GDP almost tripled in this period (Iancu and Pavelescu, 2018). In the context of continuous divergences with CMEA, Romania finalized, in 1974, the negotiations with the European Economic Community (EEC) resulting in being awarded with preferential custom rights on the European market and the introduction in the Community's Generalized System of Preferences (Mureșan, 2008). 
Consequently, Romania oriented a significant part if its external trade towards developed Western economies, including imports of Western innovative technology, but also exports of a big array of industrial products. The number of commercial partner countries increased from 110 in 1970 to 152 in 1980, and the proportion of the developed western countries in the Romanian external trade reached 37\% in 1975 (from 22\% in 1960), while the CMEA members trade decreased to 38\% in the same year (Zaman and Georgescu, 2018). This period corresponds to the gradual rejection of the control of the Soviet Union (Ben-Ner and Montias, 1991). Forest industry characterized by an increased number of products, added value and access to new (quality oriented) markets (INS, 1992). Consequently, the attention for quality increased as well as the efficient utilization of wood and the complexity of technological processes, as forest industry was addressing mainly the external market (INS, 1992).

Starting from 1980, Romania faced a foreign debt crisis and the ruling Communist Party decided its accelerated payment. The economic development stagnated and this affected the population. By the late $1970 \mathrm{~s}$ and early 1980s, difficulties in financing trade with western countries determined the leadership to orient some of Romania's trade back to the Soviet Union, exchanging low-quality products for Soviet energy and raw materials (Ben-Ner and Montias, 1991). On the account of forced exports and limited imports, the weight of western countries in Romanian external trade dropped under 25\%, while CMEA counties accounted for more than 50\% after 1985 (Zaman and Georgescu, 2018). Still, the forest industry continued to export massively, the sector contribution to country's export reaching $9 \%$ (INS, 1992), but the quality of products gradually decreased.

The fall of the communist regime in 1989 caused dramatic legal, institutional and economic changes, triggered by the transition to a market economy. Industry has been gradually privatised, and the EU has become the main external trade/investment partner of Romania (Zaman and Georgescu, 2018). The first decade after the fall of the communist regime was characterised by a dramatic economic regress determined by privatisation, need for adaptation to new markets and prolonged institutional reforms. The difficult situation of the $1990 \mathrm{~s}$ had been eventually overcome and Romania fulfilled the political and economic criteria for EU admission starting from January 1st, 2007. Initially the forest harvesting and processing sector collapsed and the roundwood exports increased. Afterwards, due to opportunities created by the opened market, and based on the previously accumulated technical expertise, forest industry has revitalized, fuelled by market pull approach (Borz et al., 2019) and private investments, many of them made by foreign investors, especially in the processing industry (APMR, 2018). The 1990s raise in round-wood exports, was reversed by an increasing export weight of finished wood products (FAOSTAT, 2020).

In the studied period, sustainability criteria adoption for forestry sector started with the decision to elaborate FM plans for all the forest area, immediately after the forest land nationalisation in 1948. The wood provision continuity was initially the central criterion of the FM planners (Duduman, 2019). However, despite these initiatives, during the SOVROM period, the forest was harvested without any sustainability concern. After that, forest resource was managed exclusively according to FM plans, elaborated based on continuously updated criteria and procedures. Between 1960 and 1989 wood provision continuity was complemented with more complex sustainability criteria related to the promotion of the natural forest type, local proveniences, mixed stands and long rotation cycles (Giurgiu, 1988). During the 70s and the 80s Romania had one of the most effective FM in the world (Popa and Pache, 2017). Long rotation cycles favoured the furniture-oriented forestry industry, based on the efficient use of wood resources (Anonimous, 1970). The fall of the communist regime triggered long and complex processes of forest land and forest industry privatisation (Abrudan, 2012), diminishing state control over the sector, although there were significant efforts to maintain the sustainable FM centralised approach, with inherent issues related to the dramatic changes in ownership and the need for institutional and regulatory updates (Popa et al., 2019). 
In the last decade (2010-2019), the end of the forest land restitution process determined a stabilisation of the sector currently benefiting from the traditional centralised FM regulatory framework, but facing challenges coming from the new socio-economic reality (Popa et al., 2019). Increasing societal interest is currently determining intense discussions related especially to the future of biodiversity conservation, accountability of harvested wood volumes (Ciceu et al., 2019) and illegal activities, in the context of new tenure structure, increasingly demanding processing industry and, consequently, governance challenges (Dragoi and Toza, 2019).

Presently, due to the sustainability criteria used by the FM planning system and effective management of forest resources, Romanian forests are known for their biodiversity (European Environment Agency, 2003). Forest covers almost a third of the land, and the share of non-state forest owners is around 50\% (INS, 2019). Wood represents an important resource for national industry, but also for local communities, the total


varied between 3.5-4.5\% in the last decades (Abrudan et al., 2009; INS 2019). At present, Romania is a net exporter of processed wood products and a net importer of round-wood (FAOSTAT, 2020). The exports of wood products had a value of 2.3 bill EUR in 2017 (including furniture), representing $88 \%$ of the national forest industry production, while the main export partners are EU countries (APMR, 2018).

\section{$\underline{\text { Romanian standardization activity }}$}

The establishment of the Standardisation Commission in 1948, through the Presidential Decree No. 334, initiated the post-war evolution of the Romanian standardisation institutional framework. It was a public, government directly subordinated body, established for supervising the standards elaboration and approval, for all economic sectors (Bejan et al., 2019). The communist regime transformed the standardization process in a very important tool for governmental economic planning - the central piece of the newly adopted centralized economy. Consequently, its importance increased, and this was mirrored in the development of the institutional frame: in 1955, the State Office for Standards and Inventions was established and, in 1970, a National Institute for Standardization (NIS) was created. The continuous upgrade of the standardisation regulatory framework, during the communist period, was triggered by the increasing need to use standards as a tool to impose a certain quality control and to facilitate the commercial exchanges and the economic efficiency in a centralized and rapidly industrializing economic system (Bejan et al., 2019). It is worth mentioning that, in a dictatorial regime in which standards were often used to impose politically driven ideas and concepts, the NIS members managed to mitigate these tendencies and achieved a reasonable balance between political influence and professional requirements of a proper standardisation process (Bejan et al., 2019). During the communist period, Romanian standardization professionals constantly fought for the adoption of the international standards provisions, Romania being the first country within the CMEA to adopt the ISO system (Bejan et al., 2019). During the communist period, all standards were mandatory by law.

After the fall of the communist regime in late 1989, the emergence of the free market economy in Romania and its connection with the European Union unique market, in accordance with the agreements signed by Romania, have caused significant changes in the standardisation regulatory framework and the entire quality assurance infrastructure. Standards were given a consensual character (Bejan et al., 2019). In 1991 Romania joined the European Committee for Standardization (CEN), and, in the following years, the newly established Romanian Standardization Association (ASRO) have been designated as a specialized body of central public administration, responsible for developing national standards and representing Romanian in the European and international standardization bodies (ASRO, 2020). This institutional and regulatory evolution is also reflected by the indicatives used in the Romanian standardization: the difference between Romanian Standards (SR) and the State Standards (STAS) is given by the period of their adoption. The STAS acronym was used from 1949 until 1992 by NIS, and the acronym was changed into SR after the establishment of ASRO (OECD, 2000). 
In figures, Romanian standardization means over 16,000 standards in all economic sectors, one third of which are aligned with European and international standards (Bejan et al., 2019). During the analysed period, the secretariats and technical committees within the national standardisation bodies have contributed significantly to Romanian external trade.

To achieve the objective of the study, the databases (ASRO, 2020; available on www.asro.ro website) containing the Romanian standards have been used. An Excel database with all forestry sector specific standards was created, including all valid and cancelled standards issued by the national standardization bodies between 1949 and 2020. According to International Classification for Standards (ICS) (ISO, 2015) these standards are grouped under 79 (Wood technology) ICS field. Standards in the database have been classified using their main scope as follows (Table 1) according to De Vries (1999): reference and terminology standards (SRT), standards for design (SD), standards for testing (ST), standards for products quality (SQ), standards for health and safety (SS) and standards for processes (SP). After grouping the standards according to their scope and year of adoption the resulted distributions have been compared, aiming to identify differences between the communist and post-communist period, but also between different economic orientation distinctive periods, as described in the Framework section. There were cases when the standards were upgraded by issuing new versions with the same scope. This was taken into consideration by also counting the cancelled standards.

Table 1. Type of standards according to their scope

\begin{tabular}{|c|c|c|c|}
\hline $\begin{array}{c}\text { Type of } \\
\text { standards }\end{array}$ & Code & Criteria & Examples \\
\hline $\begin{array}{l}\text { Reference } \\
\text { standards }\end{array}$ & SRT & $\begin{array}{l}\text { Terminology, measurement units, } \\
\text { rules of measurement, etc. }\end{array}$ & $\begin{array}{c}\text { SR EN 633: } 1997 \text { Cement chip boards. } \\
\text { Definitions and classification } \\
\text { SR EN 14076: } 2014 \text { Wood stairs. Terminology }\end{array}$ \\
\hline $\begin{array}{l}\text { Standards for } \\
\text { design }\end{array}$ & SD & $\begin{array}{l}\text { Basic requirements for design, } \\
\text { calculations, construction and } \\
\text { processes }\end{array}$ & $\begin{array}{c}\text { STAS 860-49 Wooden constructions. } \\
\text { General enforcement requirements } \\
\text { STAS 856-71 Wooden constructions. Design } \\
\text { requirements }\end{array}$ \\
\hline $\begin{array}{l}\text { Standards for } \\
\text { testing }\end{array}$ & ST & $\begin{array}{l}\text { Requirements related to test } \\
\text { methods, sampling methods etc. }\end{array}$ & $\begin{array}{l}\text { SR EN 323: } 1996 \text { Wood-based boards. } \\
\text { Determination of the volume mass } \\
\text { SR EN 322: } 1996 \text { Wood-based boards. } \\
\text { Determination of humidity }\end{array}$ \\
\hline $\begin{array}{l}\text { Standards for } \\
\text { products quality }\end{array}$ & SQ & $\begin{array}{l}\text { Products properties and value } \\
\text { intervals for use-essential } \\
\text { measurable features of products }\end{array}$ & $\begin{array}{l}\text { SR EN 12246: } 2003 \text { Quality classes of wood used } \\
\text { in pallets and packaging } \\
\text { SR 1124: 2008 Curved wood furniture. General } \\
\text { technical conditions of quality }\end{array}$ \\
\hline $\begin{array}{l}\text { Standards for } \\
\text { health and safety }\end{array}$ & SS & $\begin{array}{l}\text { Requirements regarding the } \\
\text { characteristics of products and } \\
\text { processes in order to prevent } \\
\text { usage risks }\end{array}$ & $\begin{array}{l}\text { SR EN 13525 + A2: } 2010 \text { Forestry machinery. } \\
\text { Shredders. Security } \\
\text { SR EN 60745-2-13: } 2009 \text { Portable power tools. } \\
\text { Security. Part 2-13: Particular requirements for } \\
\text { chain saws }\end{array}$ \\
\hline $\begin{array}{l}\text { Standards for } \\
\text { process }\end{array}$ & SP & $\begin{array}{l}\text { Process requisites for obtaining } \\
\text { the requested quality of products } \\
\text { related to their usage purposes }\end{array}$ & $\begin{array}{c}\text { STAS 10451-84 Wood drying technique. Drying } \\
\text { of veneers in hot air-drying plants. Technical } \\
\text { requirements } \\
\text { STAS } 10349 \text { / 1-87 Wood drying technique. } \\
\text { Drying of timber at temperatures below } 100 \\
\text { degrees C. Technical specifications }\end{array}$ \\
\hline
\end{tabular}

Presently valid standards have been grouped according their national and international recognition in order to assess the influence of external vs. internal market/context. The considered categories are defined by ASRO (ASRO, 2011): national standards (STAS and SR depending on the period of adoption, before and 
after 1989 respectively), international standards adopted as such by Romania (SR ISO), European standards adopted as such by Romania (SR ENV), Romanian standards that transposed European and international standards (SR EN ISO), Romanian standards that transposed European technical specifications (SR CEN/TS), Romanian standards that transposed CEN reports (SR CR).

\section{Results}

Valid standards vs. cancelled standards

A total of 1,894 standards were adopted for forestry sector since 1949 (Figure 2). Before 1990 (the fall of communism as a milestone), 958 standards (50.5\%) were issued: on average, 23 standards per year. The transition to the free market (after 1990) has been characterised by the elaboration of 936 standards until the elaboration of this study (on average 31 standards per year).

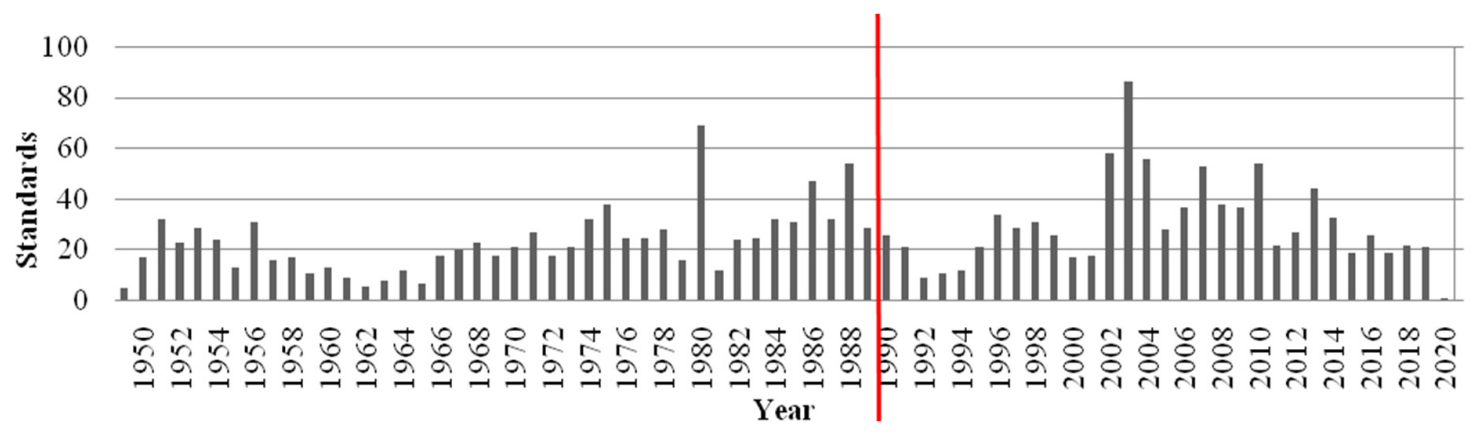

Figure 2. Issuing of Romanian standards in forestry (the red line represents the fall of the communist regime)

The oldest issued standards date from 1949 (STAS 860-49, STAS 856-49, STAS 154-49, STAS 64449, STAS 332-49), referring to the execution of wooden constructions, supporting pillars from wood or wooden sleepers for railways. These standards were addressing constructions and industrial development needs. Nevertheless, in 1950, the first standard for a more complex and elaborated wooden furniture products was also issued (STAS 1296-50).

Standards cancellation has emerged as a necessity to keep up with the technological development. Currently, in forestry industry sector there are 645 valid standards, out of which 197 were developed before 1990 (Figures 3 and 4). As expected, the older the standards the bigger the cancelation rate. The oldest valid standard was issued in 1965 (STAS 5300-65 Wooden packaging. Boxes for mine explosives).

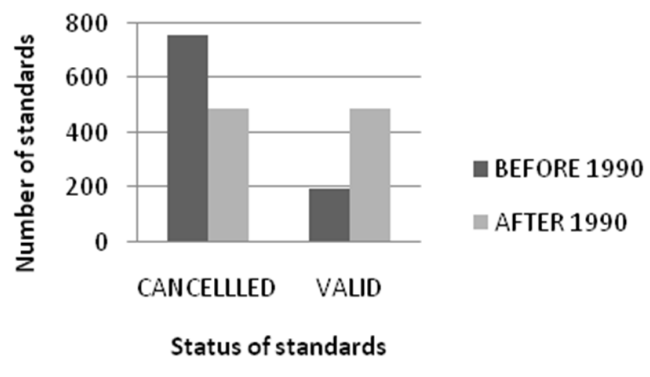

Figure 3. Current status (cancelled/valid) of forestry specific standards related to the period of issuing (sum of standards issued before and after 1990) 


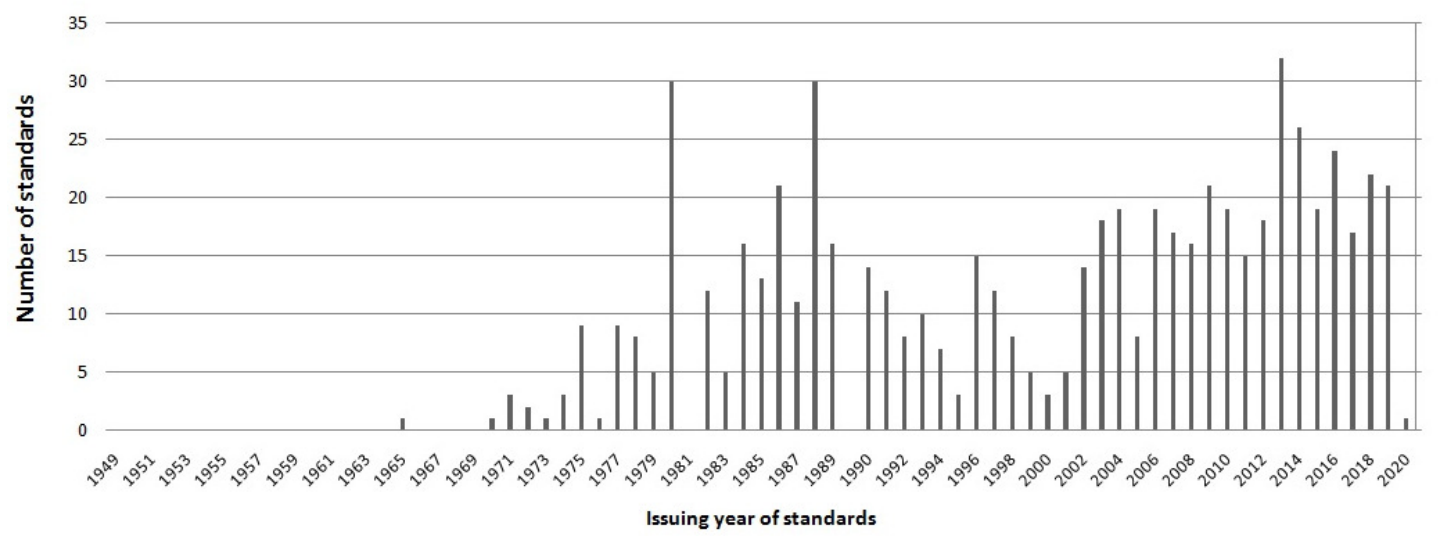

Figure 4. Valid forestry specific standards related to issuing year

The forestry sector still uses 197 standards issued prior to 1990. Some of the valid standards are not effectively in use being technologically out of date, but not requiring replacement, due to the area of use. As an example, the STAS 3144 from 1979 -Methods of measurement. Rigid wooden ruler or the STAS 5645 from 1978 Telecommunication airlines. Wooden sleepers are two valid standards that are no longer used. Also, there are SRTs, SPs (for example STAS 6236 from 1984 Wooden furniture. Finishing operations and defects) STs (for example STAS 9159 from 1989 Wood veneer.

\section{Standards according to their scope}

Out of the total number of analysed standards, SQs are the most common with a 30\% share followed closely by SRTs with $28 \%$ share. SPs have the smallest share - $2 \%$ (Figure 5a). In the communist period, SQs were predominant (462 out of 958 standards) while only 3 SSs were elaborated (Figure 5b). After 1990, SRTs are the most common (344 out of 936) while there are 53 SSs (Figure $5 \mathrm{~b}$ ). The communist period was characterized by an orientation towards SQs, SPs and SRs: $80 \%$ of the SQs, $74 \%$ of the SPs and $52 \%$ of the SRs and were elaborated before 1990. In the post-communist period, an orientation towards safety design and testing can be observed: $95 \%$ of the SSs, 84\% of the SDs and 65\% of the SRTs have been issued after 1990.
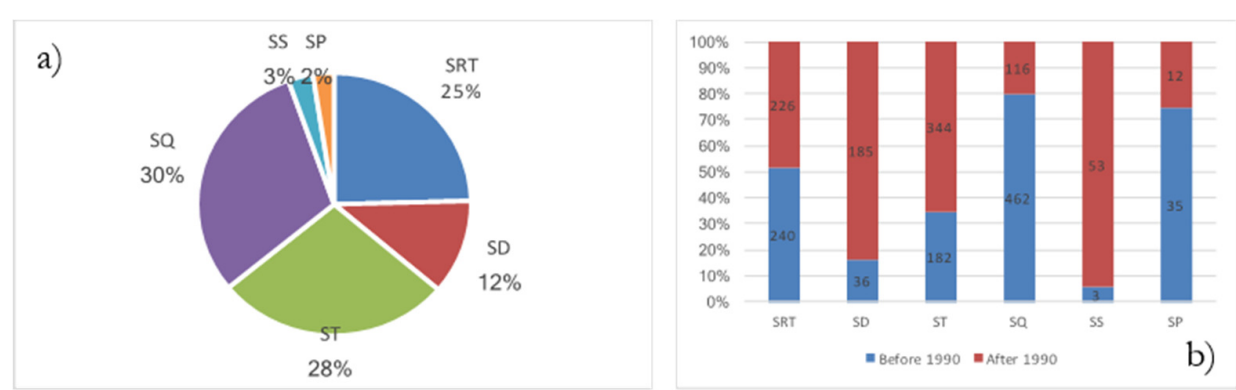

Figure 5. Distribution of analysed standards based on their scope and period of adoption: a) total number of standards $(\mathrm{N}=1894)$; b) representation of communism and after post-communism period (SRT- Reference standards; SD - Standards for design; ST - Standards for testing; SQ - Standards for products quality; SS - Standards for health and safety; SP - Standards for process)

To assess the correspondence between economic and trade evolution of Romania and the standardisation process, the standards types distribution has been done for each of the specific economic periods described in section 2.1. and Figure 1. The results can be seen in Figure 6. 




Figure 6. Distribution of analysed standards based on their scope and distinct periods of country's economic and trade evolution

SRs were issued especially in the early periods of standardisation as well as in the transition period: $23 \%$ between 1949 and 1956 and 48\% after 1990. The number of SDs, SRTs and SPs increased continuously, from period to period, during the communist time, while the number of SQs peaked between 1970 and 1979, diminishing afterwards between 1980 and 1989 (Figure 6). Notably, before 1970 there were no SSs, only one SS was issued between 1970 and 1979 and two SSs were issued between 1980 and 1989 (Figure 6).

\section{Standards recognition}

Most of the presently valid forestry sector standards benefit from international recognition (57\%) (Figure 7), indicating that the activity of the national standardization body was, after 1992, largely oriented towards adopting or transposing international or European standards.



Figure 7. Distribution of valid standards according to their recognition

(STAS - national standard issued before 1990; SR - national standard issued after 1990; SR-ISO - international standard adopted as such by Romania; SR ENV -European standard adopted as such by Romania; SR EN ISO Romanian standard that transposes European and international standard; SR CEN/TS - Romanian standard that transposes European technical specifications; SR CR - Romanian standard that transposes CEN reports).

National standards (SR and STAS) still have a significant share (43\%) but, as exemplified in section 4.1., many of the national standards are obsolete, being not used by companies anymore. 


\section{Discussion}

The results of the analysis of the standardisation process in the Romanian forestry sector indicate a very close connection between this process and the country's and sectoral economic conditions. During the communist period, the state planned economy imposed the mandatory character of the standards, thus the increasing importance of the state standardisation institutional and regulatory framework. In a market economy, standards can be developed and governed by national standardisation body or, independently, by actors holding dominant position in the market (Utterback, 1996). The consensual private standardization, when market actors pursue a leadership role in developing standards to further innovation (Xie et al., 2016), was inexistent in the communist period. The standardisation effort, although considerable, was done solely by the state, and the standards were developed according to the state own strategies in terms of innovation and economic goals. In Romanian forestry sector, the communist central authorities understood the value adding potential of the industry, as suggested by the preponderance of the SQs (almost 50\% of all issued standards). This fact, along with the significant number of SPs in comparison with the post-communist period indicates that the state seriously took over the innovation initiative, and the absence of consumer orientation, or work safety determined a very small number of SSs.

The forestry sector evolution during the communist period was marked by an increasing preoccupation for long term economic and environmental sustainability, translated in two directions: the increase of the added value and the continuous improvement in SFM approach, resulting in more than $90 \%$ of the actual forests having natural structures (IFN, 2018), even 30 years after the fall of the communist regime. During the war recovery period, between 1949 and 1956, round-wood exports to Soviet Union allowed only a very limited development of wood industry, based mainly on internal consumption of wood-based construction items. The standardisation efforts were oriented towards SRTs (the need for establishment of terminology) and SQs for construction using wooden products. The next period, between 1957 and 1970 was characterised by an increasing number of SQs, and SDs, while the SRTs decreased significantly. First STs were issued in response to the need to increase products performance and quality. Standardisation evolution indicates an increase in the use of wood for more complex and higher quality products. It is the turning point of the forest industry development, the result of the clear orientation of the Romanian state towards developing the forest industry and by that, adding more value in the national economy. The round-wood export was continuously decreasing and the export predomination (in the CMEA countries) over the internal consumption of wood products started (INS, 1992). It was the external trade openness between 1970 and 1979 (Zaman and Georgescu, 2018) that really boosted the forest industry: the round wood exports become insignificant, the number of external customers (also outside CMEA) (INS, 1992) and their diversification and quality demands increased as indicated by the significant increase in the proportion of SQs and STs. The foreign debt crisis and the external trade switching back to Soviet Union and CMEA countries (Ben-Ner and Montias, 1991) affected the forestry industry in the next period (1980-1989) especially in terms of product diversification and quality needs, mirrored by a decreasing proportion of the SQs. Seemingly, the fact that Romania diminished the adoption of modern technology imported from developed countries determined the need for internal adaptation of technological processes in the forest industry, as indicated by the increasing weight or SPs. This wasn't necessarily bad, although it affected the quality of the products, the CMEA or developing countries - the predominant external partners - not having high quality demands.

FM evolution in Romania is also closely connected with the forest sector standardisation and forest industry development. FM planning for all forest resources of the country followed by the continuous update of FM criteria based on sustainability (Duduman, 2019) favoured the continuous supply for the industry, and determined prescriptive regulations regarding the efficient utilisation of wood.

The post-communist evolution of the forestry sector, characterised by private initiative triggered development, free market and open international trade is mirrored by the standardisation, too. The last three decades are characterised by the voluntary industry agreements on product characteristics, leading to so-called 
open standard (Gandal, 2002), while the Romanian state only defines the general frame along with losing the initiative in terms of innovation. The diminished state control required new terminology and references, thus a high proportion of SRTs, while the need for forest product continuous adaptation to a quality and technologically demanding EU market is indicated by a high number of SDs, STs, many of them being European standards transposed or adopted as such by Romania. The same trend is indicated by the increased number of NWFP related standards. The decreasing innovation role of the state is indicated by the decrease of SPs and SQs proportion. An important difference can also be seen in the case of the SSs that increased 15 times in number, as a consequence of increasing consideration for customer's and worker's safety, brought by the adoption of European and other international standards.

There are studies showing that economies with centralizing tendencies transform standards into a collection of bureaucratic inefficiencies (Xie et al., 2016). From the Romanian forests sector perspective this is less valid, as long as, during the communist period, the standardisation body was very active in supporting the external trade orientation of the sector, and there was a long-term strategy that, at least until 1980, was avoiding routine and the lack of innovation. However, this approach could have leaded to missing some opportunities because the authorities and not the companies were establishing the priorities. In the Romanian case, this was balanced by the fact that market increasing requirements in terms of quantity could not affect the sustainable resource management, prescriptively and sustainable regulated by the state during the communist period. Presently, the turn to the companies based consensual standards seems to have good results for the Romanian forestry sector, confirming the fact that this approach is reducing internal quality affecting errors (Haynes et al., 2009) or miss coordination (Naveh, 2007) and, simultaneously offering productivity and quality related opportunities with expected benefits on economic sustainability.

\section{Conclusions}

This study explains how standardisation, sustainable FM and economic evolution influenced each other in the context of the Romanian forestry sector. The results can be seen as an interesting case study on how centralized state standardisation can support the efforts towards sustainability. Long term sectoral strategy centred on sustainable FM, added value and export was, at least to a significant extent, accompanied by a sustained effort in standardising the design and quality of forest products as well as the needed processes. Based on standardisation, efficient and integrated forest industry had helped prescriptively regulated sustainable FM in the communist period.

The opportunities of market economy and EU trade support a private forest industry that, despite inherent difficulties, is increasingly efficient, productive and innovative. This is advocating in the favour of the open standards approach. However, at least in the forestry sector, the state authorities should carefully address their mission of creating the proper balance and standardisation could offer very useful tools in this respect.

\section{Authors' Contributions}

Conceptualization: AFH and AIN; Investigation: BP; Methodology: AFH and AIN; Supervision: BP, NN, VM and IVA; Writing - original draft: AFH and BP; Writing - review \& editing: BP, NN, VM and IVA. All authors read and approved the final manuscript. 


\section{Acknowledgements}

This research received no specific grant from any funding agency in the public, commercial, or not-forprofit sectors.

\section{Conflict of Interests}

The authors declare that there are no conflicts of interest related to this article.

\section{References}

Abrudan IV (2012). A decade of non-state administration of forests in Romania: achievements and challenges. International Forestry Review 14(3):275-284. https://doi.org/10.1505/146554812802646684

Abrudan IV, Marinescu V, Ionescu O, Ioras F, Horodnic SA, Sestras R (2009). Developments in the Romanian forestry and its linkages with other sectors. Notulae Botanicae Horti Agrobotanici Cluj-Napoca 37(2):14-21. https://doi.org/10.15835/nbha3723468

Anonimus (1976). Programul national pentru conservarea si dezvoltarea fondului forestier ofera largi posibilitati de activitate pentru fiecare silvicultor. Revista Padurilor-Industria Lemnului. Seria: Silvicultura si Exploatarea Padurilor.

Aplet G, Jhonson N, Olson J, Sample V (1993). Defining Sustainable Forestry (Island Press).

APMR (2018). Retrieved 2020 March 16 from http://www.industriamobilei.ro

ASRO (2011). Knowing and applying the standards - essentials for existing on a competition market.

ASRO (2020). Retrieved 2020 March18 from https://www.asro.ro/

Banu F (2004). Asalt asupra economiei României [Assault on the Romanian economy]. De la Solagra la Solvrom (1936 1956). Nemira Press, Bucharest, Romania.

Baud-Lavigne B, Agard B, Penz B (2012). Mutual impacts of product standardization and supply chain design. International Journal of Production Economics 135(1):50-60. https://doi.org/10.1016/j.ijpe.2010.09.024

Baumgartner RJ (2019). Sustainable development goals and the forest sector-a complex relationship. Forests 10(2):152. https://doi.org/10.3390/f10020152

Baumgartner RJ, Ebner D (2010). Corporate sustainability strategies: sustainability profiles and maturity levels. Sustainable Development 18(2):76-89. https://doi.org/10.1002/sd.447

Baumgartner RJ, Rauter R (2017). Strategic perspectives of corporate sustainability management to develop a sustainable organization. Journal of Cleaner Production 140:81-92. https://doi.org/10.1016/j.jclepro.2016.04.146

Bejan M, Bejan B, Balan L (2019). Romanian standardization after 20 years. AGIR Bulletin 1:24-32.

Ben-Ner A, Montias JM (1991). The Introduction of markets in a hyper centralized economy: the case of Romania. Journal of Economic Perspectives 5(4):163-170. https://doi.org/10.1257/jep.5.4.163

Borz SA, Rommel D, Ziesak M, Vasiliauskas G (2019). Operational requirements and preferences towards forwarder technology. Bulletin of the Transilvania University of Brasov. Forestry, Wood Industry, Agricultural Food Engineering. Series II 12(1):1-12.

Bruce M, Daly L, Towers N (2004). Lean or agile: A solution for supply chain management in the textiles and clothing industry? International Journal of Operations and Production Management 24(2):151-170. https://doi.org/10.1108/01443570410514867

Carroll AB (1999). Corporate social responsibility: evolution of a definitional construct. Business \& Society 38(3):268295. https://doi.org/10.1177/000765039903800303

Chang RD, Zuo J, Zhao ZY, Zillante G, Gan XL, Soebarto V (2017). Evolving theories of sustainability and firms: History, future directions and implications for renewable energy research. Renewable and Sustainable Energy Reviews 72:48-56. https://doi.org/10.1016/j.rser.2017.01.029 
Ciceu A, Radu R, García-Duro J (2019). Planul Național de Contabilizare a Pădurilor pentru România. Institutul Național de Cercetare-Dezvoltare în Silvicultură „Marin Drăcea” (INCDS). Voluntari. Romania. pp 89. Retrieved 2020 May 18 from

http://www.mmediu.ro/app/webroot/uploads/files/National\%20forestry\%20accounting\%20plan\%20of\%20 Romania_RO.pdf

De Vries HJ (1999). Standardization: A business approach to the role of national standardization organizations. Springer Science \& Business Media.

Drăgoi M, Toza V (2019). Did forestland restitution facilitate institutional amnesia? Some evidence from Romanian forest policy. Land 8(6):99. https://doi.org/10.3390/land8060099

Duduman G (2019). Scurtistoric al amenajăriipădurilor din România. Bucovina Forestiera 19(2):139-158. https://doi.org/10.4316/bf.2019.019

European Environment Agency (2003). European Environment Agency Digital map of European ecological regions. Retrieved 2020 March 18 from https://www.eea.europa.eu/data-and-maps/data/digital-map-of-europeanecological-regions

FAOSTAT. Retrieved 2020 March 18 from http://www.fao.org/faostat/en/\#home

Fornasiero R, Macchion L, Vinelli A (2015). Supply chain configuration towards customization: a comparison between small and large series production. IFAC-PapersOnLine 48(3):1428-1433. https://doi.org/10.1016/j.ifacol.2015.06.287

Gandal N (2002). Compatibility, standardization, and network effects: some policy implications. Oxford Review of Economic Policy 18(1):80-91. https://doi.org/10.1093/oxrep/18.1.80

Gaurav N, Sivasankari S, Kiran G, Ninawe A, Selvin J (2017). Utilization of bioresources for sustainable biofuels: A Review. Renewable and Sustainable Energy Reviews 73:205-214. https://doi.org/10.1016/j.rser.2017.01.070

Giurgiu V (1988). Amenajarea pădurilor cu funcții multiple [Multipurpose forests management planning] Ceres. (Bucharest, Romania).

Grefrath C, Wagner D, Macchi M, Granados MH, Stermann S (2017). Methods and tools for sustainable development of products and services. Value Networks in Manufacturing. Springer Series in Advanced Manufacturing. (Springer International Publishing, Switzerland), pp 223-246.

Hamel G (2006). The why, what, and how of management innovation. Harvard Business Review 84(2):72-84. https://hbr.org/2006/02/the-why-what-and-how-of-management-innovation

Hashem G, Tann J (2007). The adoption of ISO 9000 standards within the Egyptian context: a diffusion of innovation approach. Total Quality Management and Business Excellence 18(6):631-652. https://doi.org/10.1080/14783360701349435

Hill CWL, Rothaermel FT (2003). The performance of incumbent firms in the face of radical technological innovation. Academy of Management Review 28(2):257-274. https://doi.org/10.5465/amr.2003.9416161

Hopwood B, Mellor M, O’Brien G (2005). Sustainable development: mapping different approaches. Sustainable Development 13(1):38-52. https://doi.org/10.1002/sd.244

Hurmekoski E, Jonsson R, Korhonen J, Jänis J, Mäkinen M, Leskinen P, Hetemäki L (2018). Diversification of the forest industries: role of new wood-based products. Canadian Journal of Forest Research 48(12):1417-1432. https://doi.org/10.1139/cjfr-2018-0116

Iancu A, Pavelescu FM (2018). Crestere economica, acumulare si dezechilibre în România perioadei comuniste. Studii Economice. Academia Română, Institutul Național de Cercetări Economice, Bucharest, Romania.

IFN Results of the second cycle of National Forest Inventory (2013 - 2018). Retrieved 2020 March 18 from http://roifn.ro/site/ifn-ciclul-ii/

INS (1992). Anuarul statistic al României. Retrieved 2020 March 20 from http://ins.ro

INS (2019). Statistica activităților din silvicultură, 2018 [Forestry statistics for 2018]. Retrieved 2020 March 20 from http://www.insse.ro/cms/sites/default/files/field/publicatii/statistica_activitatilor_din_silvicultura_ in_anul_2018.pdf

ISO (2015). International Classification for Standards (ICS). Retrieved 2020 March 20 from https://www.iso.org/cms/render/live/en/sites/isoorg/contents/data/publication/10/00/PUB100033.html.

ISO-IEC Guide 2 (1991). General terms and their definitions concerning standardization and related activities. Retrieved 2020 March 20 from https://www.iso.org/standard/19713.html 
Knorn J, Kuemmerle T, Radeloff VC, Keeton WS, Gancz V, Biriş IA, ... Hostert P (2013). Continued loss of temperate old-growth forests in the Romanian Carpathians despite an increasing protected area network. Environmental Conservation 40(2):182-193. https://doi.org/10.1017/S0376892912000355

Lähtinen K, Toppinen A (2008). Financial performance in Finnish large- and medium-sized sawmills: The effects of valueadded creation and cost-efficiency seeking. Journal of Forest Economics 14(4):289-305. https://doi.org/10.1016/j.jfe.2008.02.001

Le Blanc D (2015). Towards integration at last? The sustainable development goals as a network of targets. Sustainable Development 23(3):176-187. https://doi.org/10.1002/sd.1582

Lecocq X, Demil B (2006). Strategizing industry structure: the case of open systems in a low-tech industry. Strategic Management Journal 27(9):891-898. https://doi.org/10.1002/smj.544

Linser S, Wolfslehner B, Bridge S, Gritten D, Johnson S, Payn T, ... Robertson G (2018). 25 years of criteria and indicators for sustainable forest management: how intergovernmental C\&I processes have made a difference. Forests 9(9):578. https://doi.org/10.3390/f9090578

Macovei PC (2011). Principalele consecințe ale aplicării legislației în pădurile Bucovinei [The main consequences of application of the legislation on the Bukovina forests]. Geographica Timisiensis 20(1):5-11.

Marcean M (2002). Pădurile Sucevei şi calamitățile din perioada 1945-2002 [The forests of Suceava and the calamities from 1945-2002]. Bucovina Forestiera 10:1-2.

Munteanu C, Nita MD, Abrudan IV, Radeloff VC (2016). Historical forest management in Romania is imposing strong legacies on contemporary forests and their management. Forest Ecology and Management 361:179-193. https://doi.org/10.1016/j.foreco.2015.11.023

Mureșan M (2008). Romania's integration in COMECON. The analysis of a failure. The Romanian Economic Journal $11(30): 27-58$.

Naveh E (2007). Formality and discretion in successful R\&D projects. Journal of Operations Management 25(1):110125. https://doi.org/10.5465/AMBPP.2003.13792445

Nur R, Nasrullah B, Suyuti MA, Apollo (2018). Sustainable manufacturing by calculating the energy demand during turning of AISI 1045 steel. Journal of Physics: Conference Series 953:012028. https://doi.org/10.1088/1742$6596 / 953 / 1 / 012028$

OCED (2020). Organization for Economic Cooperation and Development: Review of Agricultural Policies Romania 139.

Popa B, Niță MD, Hălălișan AF (2019). Intentions to engage in forest law enforcement in Romania: An application of the theory of planned behaviour. Forest Policy and Economics 100:33-43. https://doi.org/10.1016/j.forpol.2018.11.005

Popa B, Pache RG (2016). The concept of ecosystem services - the solution to support the regulation efforts of the forestry sector in Romania. Revista Pădurilor 131(3-4):41-53.

Ramage MH, Burridge H, Busse-Wicher M, Fereday G, Reynolds T, Shah DU, Wu G (2017). The wood from the trees: The use of timber in construction. Renewable and Sustainable Energy Reviews 68:333-359. https://doi.org/10.1016/j.rser.2016.09.107

Rysman M, Simcoe T (2008). Patents and the performance of voluntary standard-setting organizations. Management Science 54:1920-1934. https://doi.org/10.1287/mnsc.1080.0919

Sample VA, Sedjo RA (1996). Sustainability in forest management: An evolving concept. International Advances in Economic Research 2(2):165-173. https://doi.org/10.1007/BF02295056

Silva ME, Figueiredo MD (2020). Practicing sustainability for responsible business in supply chains. Journal of Cleaner Production 251:119621.

Siry JP, Cubbage FW, Ahmed MR (2005). Sustainable forest management: global trends and opportunities. Forest Policy and Economics 7(4):551-561. https://doi.org/10.1016/j.forpol.2003.09.003

Stratton R, Warburton RDH (2003). The strategic integration of agile and lean supply. International Journal of Production Economics 85(2):183-198. https://doi.org/10.1016/S0925-5273(03)00109-9

Timko J, Le Billon P, Zerriffi H, Honey-Rosés J, de la Roche I, Gaston C, ... Kozak RA (2018). A policy nexus approach to forests and the SDGs: trade-offs and synergies. Current Opinion in Environmental Sustainability 34:7-12. https://doi.org/10.1016/j.cosust.2018.06.004

United Nations (2018). Goal 12: ensure sustainable consumption and production patterns. Retrieved 2020 March 16 from https://www.un.org/sustainabledevelopment/sustainable-consumption-production

Utterback JM (1996). Mastering the dynamics of innovation Nachdr. Harvard Business School, Boston, Mass. 
Van Bueren EM, Blom EM (1997). Hierarchical framework for the formulation of sustainable forest management standards. The Tropenbos Foundation, Wageningen, Netherland.

Veen P, Fanta J, Raev I, Biriş IA, de Smidt J, Maes B (2010). Virgin forests in Romania and Bulgaria: results of two national inventory projects and their implications for protection. Biodiversity and Conservation 19(6):1805-1819. https://doi.org/10.1007/s10531-010-9804-2

Voces R, Diaz-Balteiro L, Romero C (2012). Characterization and explanation of the sustainability of the European wood manufacturing industries: A quantitative approach. Expert Systems with Applications 39(7):6618-6627. https://doi.org/10.1016/j.eswa.2011.12.040

Wisniewska J (2015). The concept of sustainable development in agribusiness. Intercathedra 31(3).

Xie Z, Hall J, McCarthy IP, Skitmore M, Shen L (2016). Standardization efforts: The relationship between knowledge dimensions, search processes and innovation outcomes. Technovation 48:69-78. http://dx.doi.org/10.1016/j.technovation.2015.12.002

Zaman G, Georgescu G (2018). A retrospective study on Romania's external trade in the past 100 years. Munich Personal RePEc Archive, MPRA Paper No. 89707. Retrieved 2020 March 16 from https://mpra.ub.unimuenchen.de/89707/1/MPRA_paper_89707.pdf
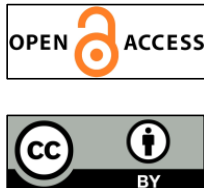

The journal offers free, immediate, and unrestricted access to peer-reviewed research and scholarly work. Users are allowed to read, download, copy, distribute, print, search, or link to the full texts of the articles, or use them for any other lawful purpose, without asking prior permission from the publisher or the author.

License - Articles published in Notulae Botanicae Horti Agrobotanici Cluj-Napoca are Open-Access, distributed under the terms and conditions of the Creative Commons Attribution (CC BY 4.0) License. (c) Articles by the authors; UASVM, Cluj-Napoca, Romania. The journal allows the author(s) to hold the copyright/to retain publishing rights without restriction. 